\title{
Characterization and expression of the hydrogenase-encoding gene from Clostridium acetobutylicum P262
}

\author{
Joseph D. Santangelo, ${ }^{1}$ Peter Dürre ${ }^{1}$ and David R. Woods ${ }^{2}$ \\ Author for correspondence: Joseph D. Santangelo. Tel: +4955139 3813. Fax: +49551393793. \\ e-mail: jsantan@gwdg.de
}

1 Institut für Mikrobiologie, Georg-August-Universität Gottingen,

Grisebachstraße 8, D-37077

Gottingen, Germany

2 Department of

Microbiology, University of

Cape Town, Rondebosch,

7700, South Africa

\begin{abstract}
The hydrogenase enzyme of Clostridium acetobutylicum plays a pivotal role in controlling electron flow, and hence carbon flow, during the complex biphasic fermentation of carbohydrates to the neutral solvents acetone and butanol. We report here the cloning and molecular characterization of the hydrogenaseencoding gene (hydA) from C. acetobutylicum P262. This gene was isolated by colony hybridization, using the Clostridium pasteurianum hydrogenase-1 gene as a probe. The DNA sequence encoding the hydA gene from $C$. acetobutylicum was determined, and revealed an ORF (1722 bp) encoding a 574 amino-acid protein. This C. acetobutylicum hydrogenase protein product has $82 \%$ similarity and $67 \%$ identity with the $C$. pasteurianum hydrogenase-1 protein. Northern blot analysis of RNA isolated from C. acetobutylicum indicates that the $C$. acetobutylicum hydrogenase protein product is translated from a monocistronic operon. RNA was isolated from the different morphological and physiological stages of a batch $C$. acetobutylicum fermentation, and further Northern blot analyses revealed no differences in the expression of the gene during acidogenesis as opposed to solventogenesis. Primer extension experiments confirmed these results and identified the 5' start of the MRNA transcript. These results correlated well with the physiological need for this organism to dispose of excess reducing equivalents.
\end{abstract}

Keywords: Clostridium acetobutylicum, hydrogenase, electron flow, byd $A$

\section{INTRODUCTION}

Clostridium acetobutylicum is well known for its ability to produce the industrially important chemical feedstocks acetone and butanol. This strictly anaerobic, Grampositive endospore-forming bacterium carries out a biphasic fermentation, where acetic and butyric acids are produced during the exponential growth phase, followed by solvent production occurring during the stationary phase (Jones \& Woods, 1986). Since the late 1970s, a considerable amount of research has gone into studying the mechanisms behind the metabolic shift to solvent production in this organism.

The importance of electron flow, with respect to regulating carbon flow, has been the topic of a number of studies (Martin et al., 1982; Kim \& Zeikus, 1985; Meyer

The GenBank accession number for the sequence reported in this paper is U09760. et al., 1986; Vasconcelos et al., 1994). Among the solventproducing clostridia, the pathways for acid production alone do not provide for the disposal of excess NADH produced during glycolysis. These organisms have the ability to produce hydrogen and therefore can process both excess electrons and protons through this route. During acidogenesis, a major portion of the electron flow is directed to hydrogen production, whereas the carbon flow is directed to acid production. Studies have shown that during the exponential growth phase more hydrogen is produced than is theoretically possible from the phosphoroclastic breakdown of pyruvate alone (Martin $e t$ al., 1982; Kim \& Zeikus, 1985), indicating that excess $\mathrm{NADH}$ is cycled through ferredoxin towards the production of hydrogen gas. In $C$. acetobutylicum the shift from acidogenesis to solventogenesis is accompanied by a decrease in hydrogen production and an increase in $\mathrm{CO}_{2}$ production. Less hydrogen is produced than would be expected from the oxidation of pyruvate, demonstrating that during the stationary phase both carbon and electron flow are primarily directed to solvent production. 
The hydrogenase enzyme plays a pivotal role in controlling the direction of electron flow, as well as the acetate: butyrate ratio (Jones \& Woods, 1986). The switch in carbon flow appears to be directly linked to the reduction of hydrogen production (Kim \& Zeikus, 1985; Meyer et al., 1986; Vasconcelos et al., 1994). Hydrogenase activity, and therefore solvent production, could be altered by changing the partial pressure of hydrogen in the culture vessel (Gapes et al., 1982), or by sparging the culture vessel with CO (Kim et al., 1984; Datta \& Zeikus, 1985; Meyer et al., 1985, 1986), a known inhibitor of hydrogenase enzymes (Thauer et al., 1974; Mortenson \& Chen, 1975). Under these conditions, an earlier onset of solventogenesis and an increase in butanol yield were observed. Because the hydrogenase was inhibited, the flow of electrons from reduced ferredoxin was shifted to the generation of NADH and NADPH via the actions of the respective ferredoxin-oxidoreductases. Stimulation of butanol production was therefore necessary for the disposal of electrons carried by these reduced pyridine nucleotides.

We report here the cloning, sequencing and mRNA analysis of the hydrogenase-encoding gene (byd $A$ ) from C. acetobutylicum $\mathrm{P} 262$, one of the latest $C$. acetobutylicum strains to be utilized for the industrial production of solvents (Spivey, 1978; Jones \& Woods, 1986). A preliminary report of the data presented here was given at the annual meeting of te Vereinigung für Allgemeine und Angewandte Mikrobiologie, Hannover, Germany, 7-9 March 1994.

\section{METHODS}

Bacterial strains, plasmids and growth conditions. C. acetobutylicum P262 (Jones et al., 1982) was used as the source of DNA. Escherichia coli strains CC118 [araD139A(ara leu) $7697 \Delta$ lacX74 pho $A \Delta 20$ galE galK thi rpsE rpoB argE(Am) rec $A 1]$ (Manoil \& Beckwith, 1985) and JM109 [rec $A 1$ end $A 1$ gyr $A 96$ thi bsdR17 supE44 $\operatorname{rel} A 1 \lambda^{-} \Delta($ lac-pro $\left.A B)\right]$ (YanischPerron et al., 1985) were used interchangeably throughout this study. The positive selection plasmid vector $\mathrm{pEcoR} 251$ was a gift from M. Zabeau, Biotechnology Business Development, Ghent, Belgium, and has been described previously (Zappe et al., 1986). Plasmid pCPH10, which contained a region of the Clostridium pasteurianum hydrogenase-1 gene (Meyer \& Gagnon, 1991), was generously donated by Jacques Meyer, DBMSMétalloprotéines, Grenoble, France.

Inoculum cultures of $C$. acetobutylicum P262 were grown under strictly anaerobic conditions in the Clostridium basal medium of O'Brien \& Morris (1971) as described by Allcock et al. (1982). Batch fermentations of $C$. acetobutylicum P262 were carried out at $34^{\circ} \mathrm{C}$ in TYG medium which contained per 1: glucose, $60 \mathrm{~g}$; yeast extract, $2 \mathrm{~g}$; tryptone, $6 \mathrm{~g}$; $\mathrm{MgSO}_{4} .7 \mathrm{H}_{2} \mathrm{O}, 0.2 \mathrm{~g}$; $\mathrm{MnSO}_{4} .4 \mathrm{H}_{2} \mathrm{O}, 10 \mathrm{mg} ; \mathrm{FeSO}_{4} .7 \mathrm{H}_{2} \mathrm{O}, 10 \mathrm{mg} ; p$-aminobenzoic acid, $2 \mathrm{mg}$; biotin, $0.1 \mathrm{mg}$; $\mathrm{KH}_{2} \mathrm{PO}_{4}, 5 \mathrm{~g}$; diammonium hydrogen phosphate, $0.6 \mathrm{~g}$; adjusted to $\mathrm{pH} 6.2$ with $\mathrm{NaHCO}_{3}$. E. coli was grown aerobically in Luria broth (LB) or on Luria agar (LA) (Sambrook et al., 1989), which was supplemented with ampicillin $\left(100 \mu \mathrm{g} \mathrm{m}^{-1}\right)$ when required for plasmid selection and maintenance.

Nucleic acid isolation and manipulation. Plasmid DNA was prepared by the alkaline hydrolysis method of Ish-Horowicz \&
Burke (1981). C. acetobutylicum P262 chromosomal DNA was prepared by the method of Marmur (1961) as modified by Zappe et al. (1986) to overcome the high nuclease activity exhibited by C. acetobutylicum (Burchhardt \& Dürre, 1990; Lin \& Blaschek, 1984). Chromosomal DNA from other $C$. acetobutylicum strains and from $E$. coli strain JM109 was prepared as described by Bertram \& Dürre (1989). Total RNA from C. acetobutylicum and $E$. coli was isolated according to the method of Oelmüller $e t$ al. (1990) as modified by Gerischer \& Dürre (1992). DNA and RNA were manipulated by standard methods (Sambrook et al., 1989); the restriction endonucleases employed were obtained from a variety of sources and used according to the manufacturers' instructions.

Colony hybridization. Colony hybridization techniques were employed for the isolation of the byd $A$ gene from a $C$. acetobutylicum P262 gene library using the $1.23 \mathrm{~kb}$ EcoRI-Acc I fragment of the $C$. pasteurianum hydrogenase-1 gene (corresponding to positions 352-1589 in the GenBank sequence CLOHDGI, accession number M62754; Meyer \& Gagnon, $1991)$ as a probe. This probe DNA was radiolabelled with $\left[\alpha^{32} \mathrm{P}\right] \mathrm{dATP}$ using a nick translation kit (Amersham) according to the manufacturer's instructions. Colonies harbouring recombinant plasmids with $C$. acetobutylicum insert DNA were duplicated onto Hybond-N nylon membranes (Amersham) which were placed on LA medium. After overnight growth at $37^{\circ} \mathrm{C}$ the membranes were placed on agar plates containing chloramphenicol $\left(170 \mu \mathrm{g} \mathrm{ml}^{-1}\right)$ and incubated at room temperature for approximately $16 \mathrm{~h}$ in order to amplify the plasmid DNA. The membranes were then processed and probed using standard techniques (Sambrook et al., 1989).

DNA:DNA and DNA: RNA hybridization. Plasmid DNA and $C$. acetobutylicum chromosomal DNA were digested to completion with the appropriate endonucleases and the resulting fragments were fractionated by electrophoresis in $0.8 \%(\mathrm{w} / \mathrm{v})$ agarose gels in Tris/acetate buffer. The DNA was transferred monodirectionally and fixed to GeneScreen-Plus nylon membranes (DuPont de Nemours) according to the manufacturer's instructions. Membranes were prehybridized for $1-3 \mathrm{~h}$ at $62^{\circ} \mathrm{C}$ in a buffer $\left(75 \mu \mathrm{cm}^{-2}\right)$ containing $0 \cdot 2 \%(\mathrm{w} / \mathrm{v})$ polyvinylpyrrolidone, $0 \cdot 2 \%(\mathrm{w} / \mathrm{v}$ ) BSA, $0 \cdot 2 \%$ (w/v) Ficoll, $1 \mathrm{M} \mathrm{NaCl}, 1 \%$ $(\mathrm{w} / \mathrm{v})$ SDS, $0.1 \%(\mathrm{w} / \mathrm{v})$ sodium pyrophosphate, $10 \%(\mathrm{w} / \mathrm{v})$ dextran sulfate, $50 \mathrm{mM}$ Tris $/ \mathrm{HCl}(\mathrm{pH} \mathrm{7.5)}$, and $100 \mu \mathrm{g}$ denatured salmon sperm DNA ml $\mathrm{m}^{-1}$. Hybridization with radiolabelled DNA fragments (approximately $1 \times 10^{7}$ c.p.m.) was carried out for approximately $16 \mathrm{~h}$ at $62^{\circ} \mathrm{C}$ (Southern, 1975).

Total RNA was separated in $1 \%(\mathrm{w} / \mathrm{v})$ denaturing formaldehyde agarose gels (Sambrook et al., 1989). The fractionated RNA was then transferred monodirectionally to Hybond-N nylon membranes (Amersham) as specified by the manufacturer. The RNA was fixed to the membrane by exposure to UV light $(254 \mathrm{~nm})$ for $2.5 \mathrm{~min}$. Hybridization with radiolabelled DNA fragments was performed as described above for Southern hybridization, except that salmon sperm DNA was omitted from the hybridization solution and the hybridization temperature was reduced to $55^{\circ} \mathrm{C}$.

Probes used for the Southern and Northern hybridization experiments were labelled with $\left[\alpha_{-}{ }^{32} \mathrm{P}\right] \mathrm{dATP}$ using the random primers DNA labelling system of Gibco/BRL Life Technologies according to the manufacturer's instructions.

Nucleotide sequencing. A 1026 bp $S_{s p I}$ DNA fragment, containing the majority of the $C$. acetobutylicum byd $A$ gene, was subcloned into the EcoRV site of Bluescript plasmid SK (Stratagene). Progressive deletions of this subclone from both the $5^{\prime}$ and $3^{\prime}$ ends of the insert were generated by unidirectionally 
digesting $K p n \mathrm{I}-A c c \mathrm{I}$ and $S a c \mathrm{I}-X b a \mathrm{I}$ fragments with exonuclease III (Henikoff, 1984). The deletions were transformed into $E$. coli CC118 and transformants were selected on LA containing ampicillin $\left(100 \mu \mathrm{g} \mathrm{ml}^{-1}\right)$.

Nucleotide sequencing was carried out by the dideoxynucleotide triphosphate chain-termination method developed by Sanger et al. (1977) according to the protocol outlined by Tabor \& Richardson (1987), using the $\mathrm{T} 7$ sequencing kit (Pharmacia Biotech). The nucleotide and deduced amino acid sequences were analysed on a VAX 6000-330 computer using the Genetics Computer Group suite of sequence analysis programs (Devereux et al., 1984).

Primer extension. Primer extension studies were performed as previously described (Gerischer \& Dürre, 1992), except that SuperScript-plus reverse transcriptase (Gibco/BRL Life Technologies) was employed. A 17 -mer oligonucleotide (5'TTTGCTAGGGCAGCTTG-3'), which is complementary to the $5^{\prime}$ end of the byd $A$ transcript, was radiolabelled at the $5^{\prime}$ end with $\left[\gamma^{32} \mathrm{P}\right]$ ATP with the aid of T4 polynucleotide kinase (Gerischer \& Dürre, 1992). In order to determine the exact start point (5'-terminus) of the mRNA, the cDNA was electrophoresed next to a standard sequencing reaction which was prepared using the same 17-mer oligonucleotide.

\section{RESULTS}

\section{Gene identification and Southern hybridization}

The cloned $C$. acetobutylicum byd $A$ gene was isolated from a gene library via colony hybridization. Southern hybridization experiments were performed in order to locate the position of this gene within the $5.4 \mathrm{kbp}$ insert DNA of the clone (p9B8) using the $1.2 \mathrm{~kb}$ EcoRI-AccI C. pasteurianum hydrogenase-1-encoding fragment as a probe. A $1026 \mathrm{bp}$ SspI fragment and a 2492 bp HindIII fragment yielded positive hybridization signals and these fragments were subcloned into the Bluescript vector SK, resulting in plasmids $\mathrm{pS} 12$ and $\mathrm{pH} 12$, respectively. Plasmid $\mathrm{pH} 12$ was not initially used for DNA sequence analysis, as it was also shown to hybridize to a pEcoR251 vector only probe. However, this plasmid did prove to be useful for both DNA hybridization experiments and nucleotide sequencing as it contained the entire $C$. acetobutylicum byd $A$ gene and only $225 \mathrm{bp}$ of pEcoR251 vector DNA. Therefore, $\mathrm{pH} 12$ contained one of the vector-insert junctions from the original clone $\mathrm{p} 9 \mathrm{~B} 8$.

Further Southern hybridization experiments confirmed that the cloned insert DNA on plasmid p9B8 did indeed originate from a contiguous $C$. acetobutylicum chromosomal fragment. Sequence data revealed the presence of two Sau3AI restriction endonuclease sites (Fig. 1), and since the $C$. acetobutylicum gene library was constructed using chromosomal DNA which was partially digested with Sau3AI (Zappe et al., 1986), it was important to determine that this sequenced region was not the result of a multiple ligation event. The byd $A$-containing $S_{s p} \mathrm{I}$ fragment (bases 409-1435 in Fig. 3) was radiolabelled and used as a probe for these hybridization studies. Chromosomal DNA isolated from $C$. acetobutylicum P262 and plasmid DNA from clone $\mathrm{pH} 12$ were digested with $S_{s t \mathrm{I}}$ and HindIII endonucleases and the resulting fragments were separated by electrophoresis and blotted onto nylon membranes.

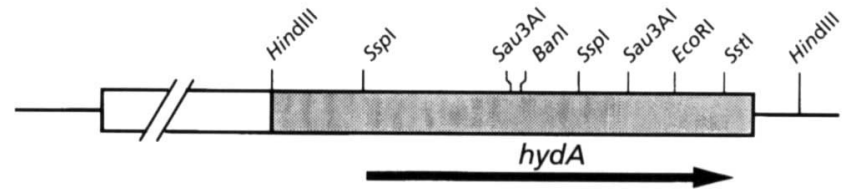

Fig. 1. Diagrammatic representation of the hydA-containing clone p9B8. The thick shaded bar represents the $2267 \mathrm{bp}$ region for which the nucleotide sequence data was determined. The thick open bar represents the approximately $3.5 \mathrm{kbp}$ of unsequenced $C$. acetobutylicum insert DNA in clone p9B8. The thin lines represent pEcoR251 vector DNA. The hydrogenaseencoding region between the insert and vector Hind III sites was subcloned into Bluescript SK to yield plasmid pH12 (see text). The location and direction of transcription for the hydA gene is indicated by the thick black line below the diagram.

The $S_{s p \mathrm{I}}$ probe fragment hybridized to an $S_{s t \mathrm{I}-H i n \mathrm{dIII}}$ fragment of identical size $(2128 \mathrm{bp})$ in both the digested C. acetobutylicum $\mathrm{P} 262$ chromosomal DNA and $\mathrm{pH} 12$ plasmid DNA (Fig. 2). Since both Sau3AI restriction endonuclease recognition sites are internal to this $2128 \mathrm{bp}$ SstI-HindIII fragment, it can be concluded that the sequenced byd $A$-containing region represents a single chromosomal fragment.

Additional DNA hybridization experiments were performed in order to obtain information about the byd $A$ genes from other $C$. acetobutylicum strains. Apart from $C$. acetobutylicum P262, chromosomal DNA from strains DSM 792, DSM 1731, ATCC 824 and NCIMB 8052 was used for these hybridization experiments. Three representative blots are presented here, where the chromosomal DNAs were digested with $S s p$ I, HindIII and

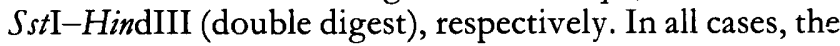
1026 bp radiolabelled $S_{s p I}$ fragment described above was employed as a probe. Equal sized hybridization signals

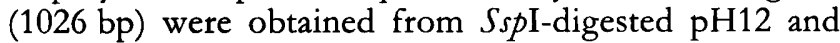
chromosomal DNA from $C$. acetobutylicum strains P262, DSM 792, DSM 1731 and ATCC 824. No positive hybridization signal was obtained with NCIMB 8052 chromosomal DNA. Similarly, these chromosomal DNAs were digested with HindIII and analysed via Southern hybridization (Fig. 2). In this case, plasmid $\mathrm{pH} 12$ was not included as there is only one HindIII recognition site in the insert DNA of this plasmid and no similarly sized fragment would be expected in the chromosomal digests. A single fragment in HindIII-digested P262 chromosomal DNA, with an approximate size of $2.6 \mathrm{kbp}$, hybridized with the $S s p$ I probe. HindIII-digested chromosomal DNA from the three $C$. acetobutylicum strains DSM 792, DSM 1731 and ATCC 824 yielded identical hybridization patterns with two DNA fragments (approx. 1.7 and $0.9 \mathrm{kbp}$ ) having positive hybridization signals. Again, no hybridization signal was obtained with chromosomal DNA isolated from the $C$. acetobutylicum strain NCIMB 8052. In the third blot (Fig. 2), pH12 plasmid DNA along with the five different chromosomal DNAs, were digested with HindIII and $S_{s t}$ I. As stated previously, identically sized signals (2128 bp) were obtained with the $\mathrm{pH} 12$ and P262 DNA. Chromosomal DNA from the three strains 
(a)

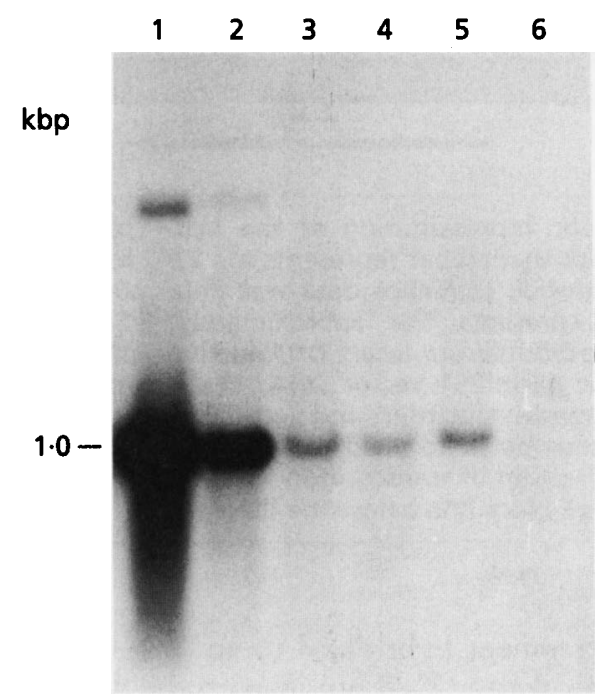

(b)

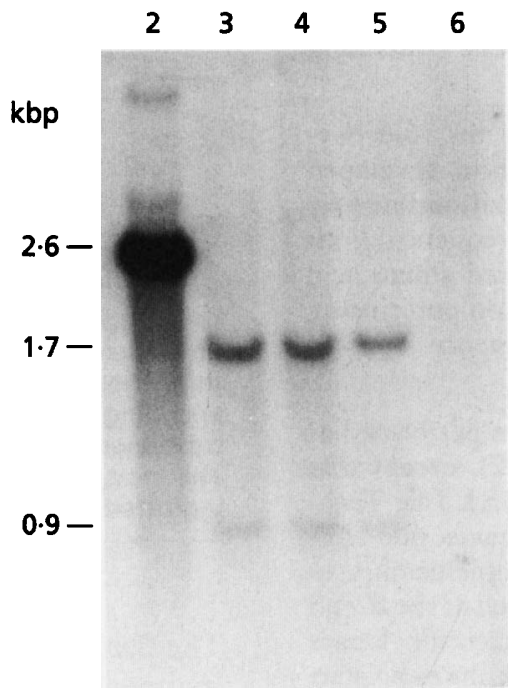

(c)

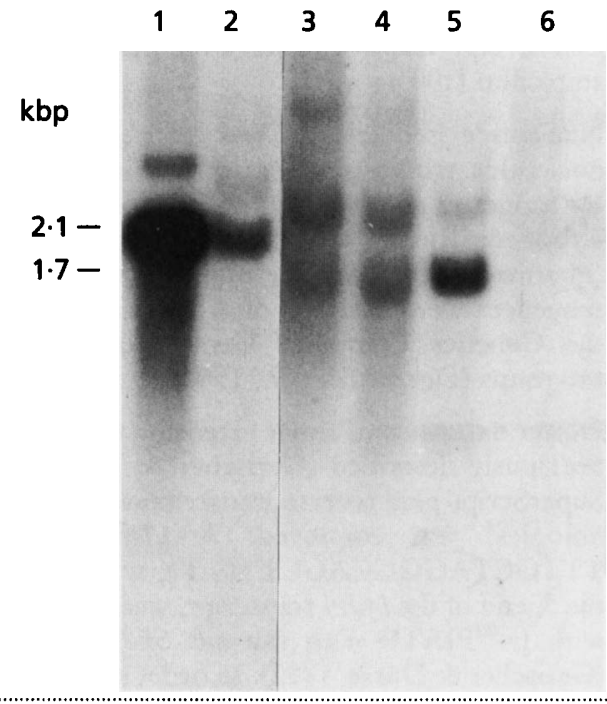

Fig. 2. Hybridization of the hydA-containing, $1026 \mathrm{bp}$ Sspl fragment to chromosomal DNA from five different $C$. acetobutylicum strains. DNA was digested with Sspl (a), HindIII (b) and HindIII-SstI (c). Lanes: 1 (a and c only), pH12 plasmid DNA; 2-6, C. acetobutylicum chromosomal DNA from strains P262, DSM 792, DSM 1731, ATCC 824 and NCIMB 8052, respectively. The autoradiogram signal sizes $(\mathrm{kbp})$ are indicated to the left of each panel. Weaker signals were presumed to be due to incomplete DNA digestion.

DSM 792, DSM 1731 and ATCC 824 showed a major hybridization signal with a size of approximately $1.7 \mathrm{kbp}$. The logical conclusion is that this $1.7 \mathrm{kbp}$ signal is analogous to the $1.7 \mathrm{kbp}$ signal obtained with the HindIIIdigested chromosomal DNAs. As seen in the first two blots, no hybridization signal was observed with chromosomal DNA from the NCIMB 8052 strain.

\section{Nucleotide sequence}

The nucleotide sequences of both strands of the insert DNA contained in plasmid $\mathrm{pS} 12$ were determined using overlapping DNA fragments generated by exonuclease III digestion. Unfortunately, this 1026 bp $S_{s p \text { I fragment }}$ did not contain the entire byd $A$ gene (bases 409-1435 in Fig. 3), and the remaining sequence data were therefore obtained from plasmid $\mathrm{pH} 12$ using 'primer walking' techniques. These sequence data revealed the presence of one complete ORF (574 amino acids), which encodes the byd $A$ gene, and is represented by bp 456-2177 (Fig. 3). This coding region is preceded by a $145 \mathrm{bp}$ intergenic region, and a putative ribosome-binding site (AGGAGC) was located $10 \mathrm{bp}$ upstream of the ATG start codon. An invert repeat, characteristic of factor-independent terminators (Brendel \& Trifonov, 1984), was located downstream of the byd $A$ gene (bp 2207-2246).

\section{Amino acid similarity}

The deduced amino acid sequence encoded by the $C$. acetobutylicum byd $A$ gene was used to search the GenBank, EMBL, SWISS-protein, NBRF-nucleic, and NBRF-protein databases with the BLASTP and TBLASTN computer programs (Altschul et al., 1990). As expected, there was considerable sequence similarity between the $C$. acetobutylicum $\mathrm{HydA}$ protein sequence and the hydrogenase-1 protein sequence from $C$. pasteurianum (Meyer \& Gagnon, 1991). The amino acid sequences of other [Fe] hydrogenases also showed a high degree of similarity to the $C$. acetobutylicum HydA protein sequence. These included the large subunits ( $\alpha$-subunit) of the [Fe] hydrogenases from both Desulfovibrio vulgaris subsp. vulgaris (Voordouw \& Brenner, 1985) and Desulfovibrio vulgaris subsp. oxamicus (Voordouw et al., 1989), the $\gamma$-hydrogenase (HydC) from D. vulgaris subsp. vulgaris (Stokkermans et al., 1989) and the fourth subunit of the potential NAD-reducing hydrogenase from Desulfovibrio fructosovorans (S. Malki and others, unpublished, GenBank accession number U07229). GAP, the alignment program based on the method of Needleman \& Wunsch (1970), was used to compare the deduced amino acid sequence from the C. acetobutylicum byd $A$ gene to the amino acid sequences of the above mentioned hydrogenases. The amino acid sequence of the $C$. pasteurianum hydrogenase- 1 contained $67 \%$ identical residues and $82 \%$ similar residues to the $C$. acetobutylicum $\mathrm{HydA}$ protein. The amino acid sequences of the $D$. vulgaris subsp. vulgaris hydrogenase $\alpha$-subunit, the $D$. vulgaris subsp. oxamicus hydrogenase $\alpha$-subunit, the $D$. vulgaris $\gamma$-hydrogenase, and the fourth subunit of the D. fructosovorans NAD-reducing hydrogenase showed 43 , 42,38 and $43 \%$ identity and $61,63,59$ and $64 \%$ similarity to the HydA protein sequence, respectively.

\section{Determination of transcript size}

RNA was isolated from acid-producing and solventproducing $C$. acetobutylicum P262 cells which were grown in TYG medium. When cultivated under these conditions, 


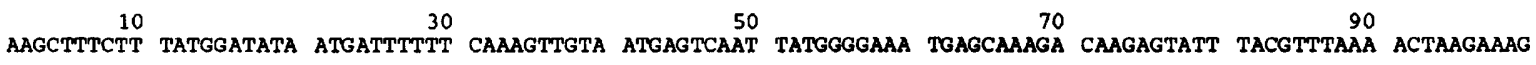

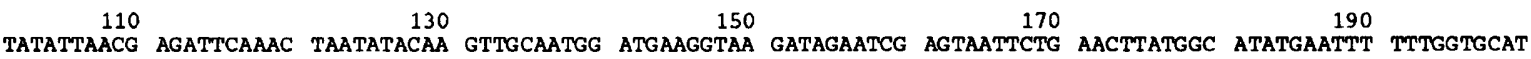

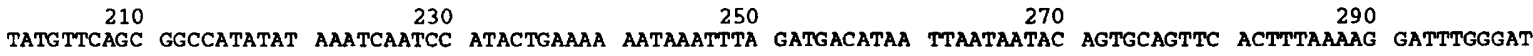

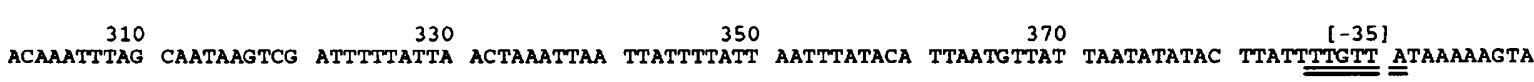
[-10] ImRNA 430 SD $450 \quad 470$ 490 TGTTAAAATA TTAACGTATT AAAAAATAAT TGTATGTGAA GGAGCATTTT ATTTAATGAT AAACATAGTA ATTGATGAaA AaACTATTCA AGTACAGGAA

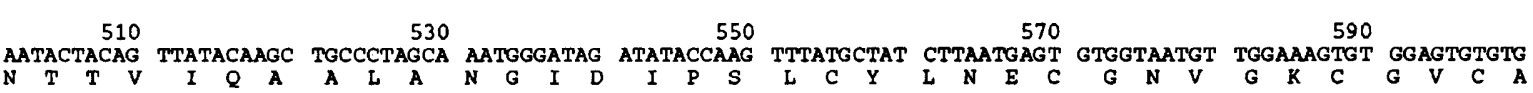

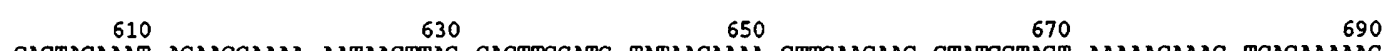

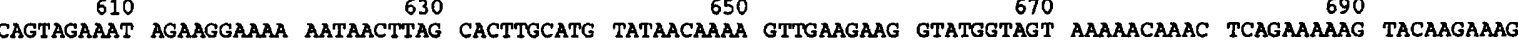

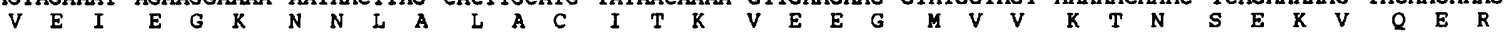
$710 \quad 730 \quad 750 \quad 770 \quad 790$

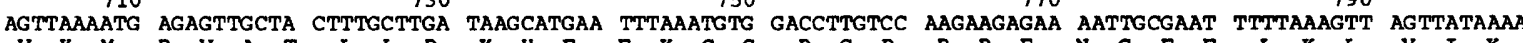
$\begin{array}{llllllllllllllllllllllllllllllllll}V & K & M & R & V & A & T & \text { L } & \text { L } & D & K & H & E & F & K & C & G & P & C & P & R & R & E & N & C & E & F & L & K & L & V & I & K\end{array}$ $\begin{array}{rrr}810 & 830 & 850\end{array}$

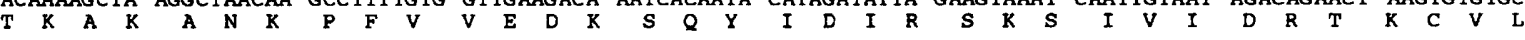

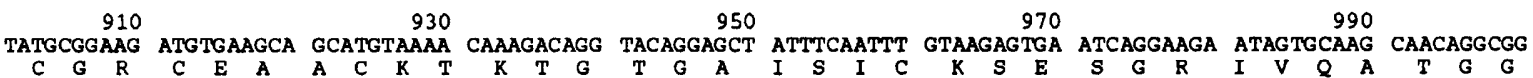
$1010 \quad 1030 \quad 1050 \quad 1070 \quad 1090$ AAAGTGCTTT GATGATACAA ATTGTTTATT ATGTGGACAA TGCGTTGCAG CATGTCCAGT AGgAGCTTTA ACTGAAAAAA CACACGTTGA TAGAGTTAAA

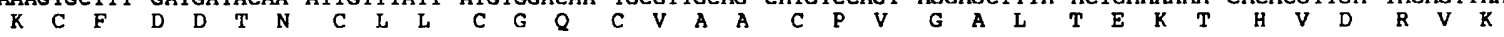
$1110 \quad 1130 \quad 1150 \quad 1170 \quad 1190$ GAAGCATTAG AAGATCCTAA TAAGCATGTA ATAGTTGCTA TGGCACCATC AATCAGAACT TCTATGGGAG AgTtATTTAA ATTAGgCTAT GgGGTTGATG

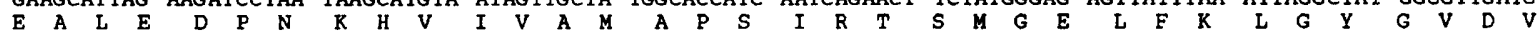
$1210 \quad 1230 \quad 1250 \quad 1270 \quad 1290$

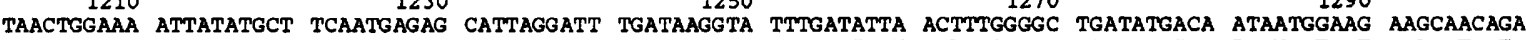
$\begin{array}{llllllllllllllllllllllllllllllllllll}T & G & K & L & Y & A & S & M & R & A & L & G & F & D & K & V & F & D & I & N & F & G & A & D & M & T & I & M & E & E & A & T & E\end{array}$

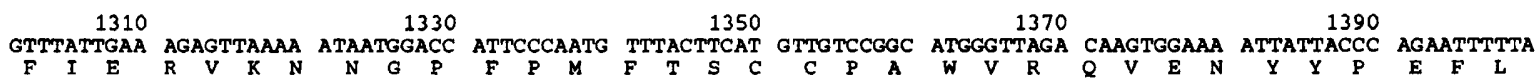
$1410 \quad 1430 \quad 1450 \quad 1470 \quad 1490$ GAAAACTTAT CATCAGCTAA ATCACCACAA CAAATATTTG GTGCAGCAAG CAAAACATAC TATCCTCAAA TATCAGGTAT AagtGCTAAA GATGTATTTA $1510 \quad 1530 \quad 1550 \quad 1570 \quad 1590$

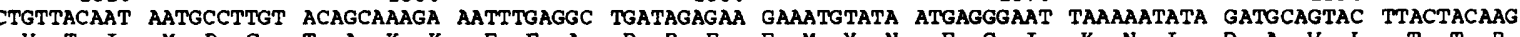
$1610 \quad 1630 \quad 1650 \quad 1670 \quad 1690$

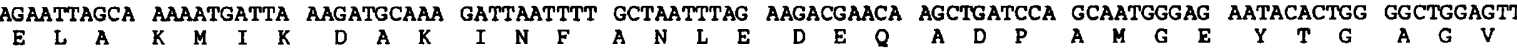
$1710 \quad 1730 \quad 1750 \quad 1770 \quad 1790$

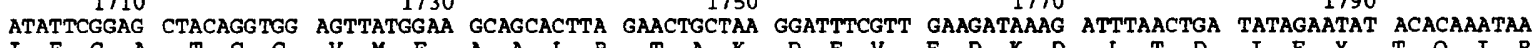
$\begin{array}{lllllllllllllllllllllllllllllllllll}I & F & G & A & T & G & G & V & M & E & A & A & L & R & T & A & X & D & F & V & E & D & K & D & L & T & D & I & E & Y & T & Q & I & R\end{array}$ $1810 \quad 1830 \quad 1850 \quad 1890$

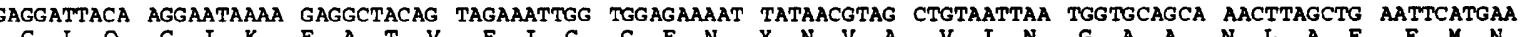

$$
\begin{array}{cccccccc}
1910 & & 1930 & & 1950 & 1970 & 1990
\end{array}
$$

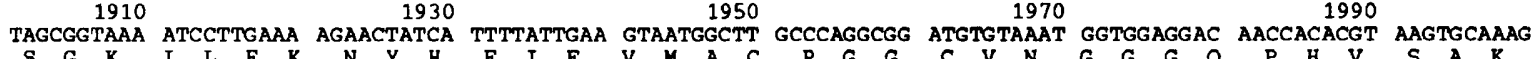
$\begin{array}{lllllllllllllllllllllllllllllllllll}S & G & K & I & \text { L } & \text { E } & K & \text { N } & \text { Y } & \text { H } & \text { F } & \text { I } & \text { E } & \text { V } & M & \text { A } & C & \text { P } & G & G & C & V & N & G & G & G & Q & P & H & V & S & A & K\end{array}$ $2010202030 \quad 200702090$

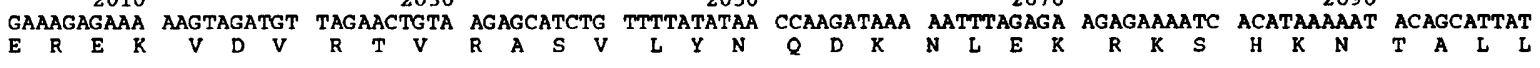
$2110 \quad 2130 \quad 2150 \quad 2170 \quad 2190$

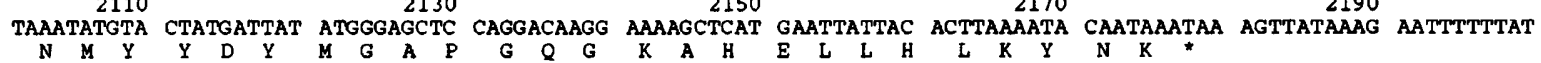

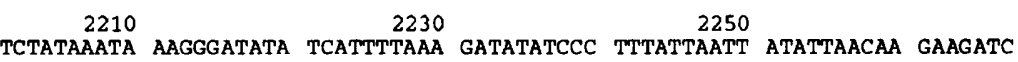

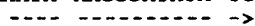

Fig. 3. Nucleotide sequence of the hydA gene and flanking regions from $C$. acetobutylicum. The deduced amino acid sequence is provided in single-letter code from nucleotide positions 456-2177 (574 amino acid residues). The mRNA start point (position 416), determined from primer extension experiments, is indicated above the nucleotide sequence. The -10 and -35 promoter regions and the proposed ribosome-binding site (SD) are double underlined and labelled above the sequence. The identification of an inverted repeat sequence, capable of forming a stem-loop structure, is shown by dashed lines below the sequence (position 2207-2246). 


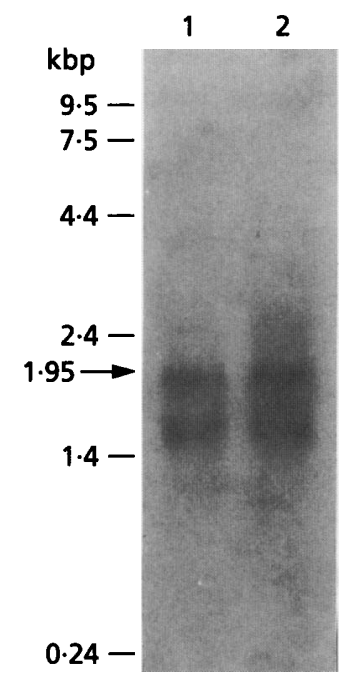

Fig. 4. Hybridization of the hydA-containing, $1026 \mathrm{bp}$ Sspl fragment to total RNA (15 $\mu \mathrm{g}$ each) isolated from acidogenic (lane 1) and solventogenic (lane 2) C. acetobutylicum P262 cells. The locations of RNA size markers are shown to the left of the autoradiogram, and an arrow indicates the position and size of the hydA transcript.

C. acetobutylicum $\mathrm{P} 262$ follows a sufficiently synchronous developmental cycle to allow for correlative morphological, physiological and biochemical studies (Woods \& Jones, 1986). Results from Northern hybridization analysis suggest that the byd $A$ gene is expressed at the same level during both acidogenesis and solventogenesis, and the transcript size was estimated to be approximately $1.95 \mathrm{kbp}$ (Fig. 4). Identical results were obtained with RNA isolated from E. coli cells which contained either plasmid $\mathrm{p} 9 \mathrm{~B} 8$ or plasmid $\mathrm{pH} 12$ (data not shown). The same byd $A$-containing $S s p$ I fragmant (bases 409-1435 in Fig. 3) used for the Southern hybridization studies was also employed as a probe for these Northern hybridization studies. A second hybridization signal, with an approximate size of $1.65 \mathrm{kbp}$, was also observed. Since $1.65 \mathrm{kbp}$ is not large enough to encode for the entire byd $A$ gene, it was assumed that this signal was a result of non-specific binding to $16 \mathrm{~S}$ rRNA (approximate size $1.7 \mathrm{kbp}$ ).

\section{Determination of $5^{\prime}$ mRNA start point}

Total RNA isolated from both acid-producing and solvent-producing cells, as well as $E$. coli containing plasmid pH12, was utilized for primer extension analysis. Total RNA isolated from $E$. colicells which harboured the Bluescript vector pSK (no insert) was used as a negative control, and in this case no primer extension signal was observed (data not shown). The results of the primer extension experiments (Fig. 5) revealed one major signal which indicates that the $5^{\prime}$ end of the byd $A$ transcript lies $40 \mathrm{bp}$ upstream of the ATG initiation codon, with $\mathrm{G}$ being the first transcribed nucleotide (see also Fig. 3). No difference was observed, with respect to the start point or signal intensity, between RNA isolated from acid-pro-

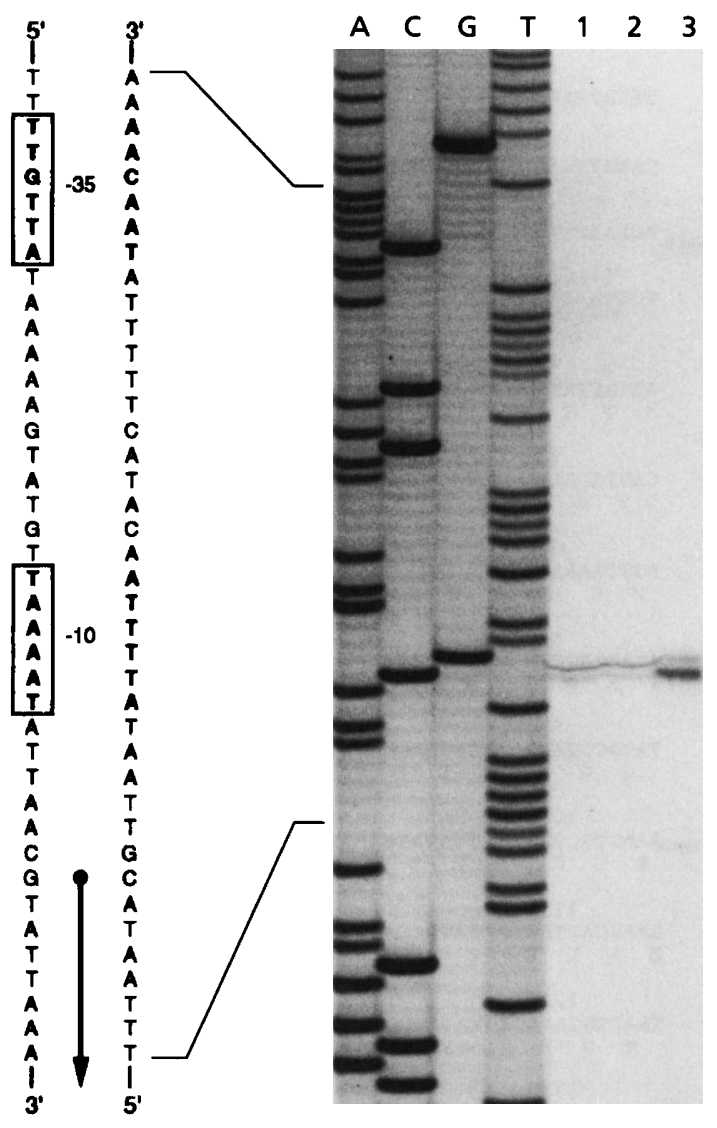

Fig. 5. Identification of the $5^{\prime}$ end of the $C$. acetobutylicum hydA transcript by primer extension analysis. A 17-mer oligonucleotide (see text) was annealed to total RNA (15 $\mu \mathrm{g}$ each) from acidogenic (lane 1) and solventogenic (lane 2) $C$. acetobutylicum P262 cells, as well as to total RNA (15 $\mu \mathrm{g})$ from E. coli cells which harboured plasmid pH12 (lane 3). A, C, G and $T$ are the products of the sequencing reaction obtained with the same 17-mer oligonucleotide as the primer. The depicted sequence (left of the autoradiogram) indicates the proposed -10 and -35 promoter regions (boxed in sense strand), and the arrow identifies the start point and direction of transcription.

ducing and solvent-producing $C$. acetobutylicum cells. The same signal was seen with RNA isolated from E. coli cells which contained plasmid pH12. A second, slightly stronger signal was also observed with RNA isolated from this E. coli clone, which corresponds to a transcript that is one nucleotide shorter than that observed with the C. acetobutylicum RNA. The observation that the strongest signal was obtained with RNA isolated from the $E$. coli $\mathrm{pH} 12$ clone is most likely a function of the high copy number of the Bluescript plasmid vector.

\section{DISCUSSION}

The low $\mathrm{G}+\mathrm{C}$ content of $C$. acetobutylicum and $C$. pasteurianum, as well as a similarly restrictive codon bias within this genus, allowed the isolation of the $C$. acetobutylicum P262 byd $A$ gene via colony hybridization 
using the C. pasteurianum hydrogenase- 1 gene as a probe. In retrospect, we can now calculate that the DNA sequence of the $C$. pasteurianum probe used for colony hybridization shares a $72 \%$ identity with the analogous region in the cloned $C$. acetobutylicum byd $A$ gene. $\mathrm{Ob}$ viously, this level of homology was sufficient to allow cross hybridization under the stringency conditions used.

Enough sequence data were obtained to reveal the presence of an additional ORF upstream of the byd $A$ gene, and a 102 amino-acid-length protein sequence could be deduced. Searches of the various protein and nucleic acid databases showed that this 102 amino-acid sequence was similar to the $\mathrm{C}$-terminal end of a protein sequence coded by a DNA region upstream of the $C$. pasteurianum hydrogenase-1 gene. This coding region from the $C$. pasteurianum chromosome (complement of bp 4608-5180; GenBank accession number Z28353) would be transcribed in the opposite direction to the hydrogenase-1 gene from this organism, which is not the case in $C$. acetobutylicum. Although these two organisms may contain analogous genes upstream of their respective hydrogenases, the configurations are somewhat different, and further sequence data and biochemical studies are required to determine their roles and organization.

DNA hybridization studies showed that the $C$. acetobutylicum P262 byd $A$ gene did not hybridize to chromosomal DNA isolated from strain NCIMB 8052 under the stringency conditions used. Hybridization signals were observed with chromosomal DNA isolated from $C$. acetobutylicum strains DSM 792, DSM 1731 and ATCC 824 (Fig. 2). In all cases the hybridization patterns obtained using chromosomal DNA from these strains were identical. It appears that the organization of the hydrogenaseencoding regions in these three $C$. acetobutylicum strains is essentially identical. This is in good agreement with the results reported by Wilkinson \& Young (1993), where it was shown that $C$. acetobutylicum strains DSM 1731 and ATCC 824 have an almost identical genome organization, and supports the results of Sauer \& Dürre (1993), who showed that the cloned C. acetobutylicum DSM 792 bsp18 gene hybridized to identically sized chromosomal DNA fragments from strains DSM 792 and ATCC 824. The hydrogenase-encoding region of the P262 strain is significantly different to yield a hybridization pattern that is distinguishable from the other strains tested, and it is also important to note that the hybridization signal was always weaker with chromosomal DNA from the other strains as compared to chromosomal DNA from the source organism.

The $C$. acetobutylicum $\mathrm{P} 262$ byd $A$ coding region is 1722 bp in length and encodes for a 574 amino-acid protein with a predicted molecular mass of approximately $63 \mathrm{kDa}$. The amino acid sequence of this protein showed considerable similarity only to other [Fe] hydrogenases, particularly the $C$. pasteurianum protein, and supports the observation that $[\mathrm{Fe}]$ hydrogenases are unrelated to $[\mathrm{NiFe}(\mathrm{Se})]$ hydrogenases (Voordouw et al., 1989). An alignment of the $C$. acetobutylicum HydA amino acid sequence with the $C$. pasteurianum hydrogenase- 1 sequence and with the se- quence of the putative fourth subunit of the $D$. fructosovorans NAD-reducing hydrogenase is shown in Fig. 6. Overall, these three amino acid sequences are remarkably similar, with the two clostridial sequences being slightly shorter than that from $D$. fructosovorans. The other [Fe] hydrogenase amino acid sequences referred to previously were not included in the alignment because their difference in sequence length would necessitate the introduction of large gaps into the aligned sequences.

Meyer \& Gagnon (1991) noted the presence of three domains in the $C$. pasteurianum hydrogenase-1 protein, based on the location of 22 cysteine residues. All 22 residues are conserved in the $C$. acetobutylicum $\mathrm{HydA}$ protein sequence, with one additional cysteine residue present at position 175 (Fig. 6). The N-terminal domain, amino acids 1-120 (Fig. 6), contains eight cysteine residues in the two clostridial sequences, and seven cysteine residues in the $D$. fructosovorans sequence. Despite their atypical arrangement, these eight cysteine residues function as ligands for two of four [4Fe-4S] clusters (Adams, 1990; Meyer \& Gagnon, 1991). An unusual distribution of cysteine residues in [4Fe-4S] clusters has been noted elsewhere (Hausinger \& Howard, 1983; Cunningham et al., 1989; Beinert, 1990). The eight cysteine residues in the central domain (amino acids 140-220, Fig. 6) are distributed in a typical ferredoxin-like pattern and function as ligands for the remaining two [4Fe-4S] clusters. Compared to the $D$. fructosovorans protein and the HydC protein from $D$. vulgaris (not shown), the $C$. pasteurianum and $C$. acetobutylicum proteins contain one and two additional cysteine residues in this domain, respectively. The C-terminal domain, which contains the necessary ligands for the hydrogen activating $\mathrm{H}$ cluster, is characterized by five conserved cysteine residues (Fig. 6). Notably, four methionine residues are also conserved between the $C$. acetobutylicum and $C$. pasteurianum proteins. It has been suggested that some or all of these methionine residues could also function as ligands in the H cluster (Meyer \& Gagnon, 1991).

Regulation of hydrogen production in $C$. acetobutylicum has been discussed in a number of studies (Gapes et al., 1982; Andersch et al., 1983; Kim \& Zeikus, 1985; Yerushalmi \& Volesky, 1985; Vasconcelos et al., 1994). Kim \& Zeikus (1985) observed that the specific rate of hydrogen production decreased in stages during the course of a batch fermentation, where the highest rate of hydrogen production occurred during the initial exponential growth phase. These authors noted a significant decrease in the rate of hydrogen production which correlated with the shift from acid production to solvent production. The specific hydrogenase activity in whole cells from acid-producing cultures was shown to be approximately $2 \cdot 2$-fold higher than that measured from solvent-producing cultures (Kim \& Zeikus, 1985). It was concluded that because hydrogenase activity was not affected by either $\mathrm{pH}$ or acid concentration, the decrease in hydrogen production during solventogenesis is a result of regulation of hydrogenase production as opposed to an inhibition of enzyme activity. In contrast to these conclusions, Andersch et al. (1983) reported that hydro- 

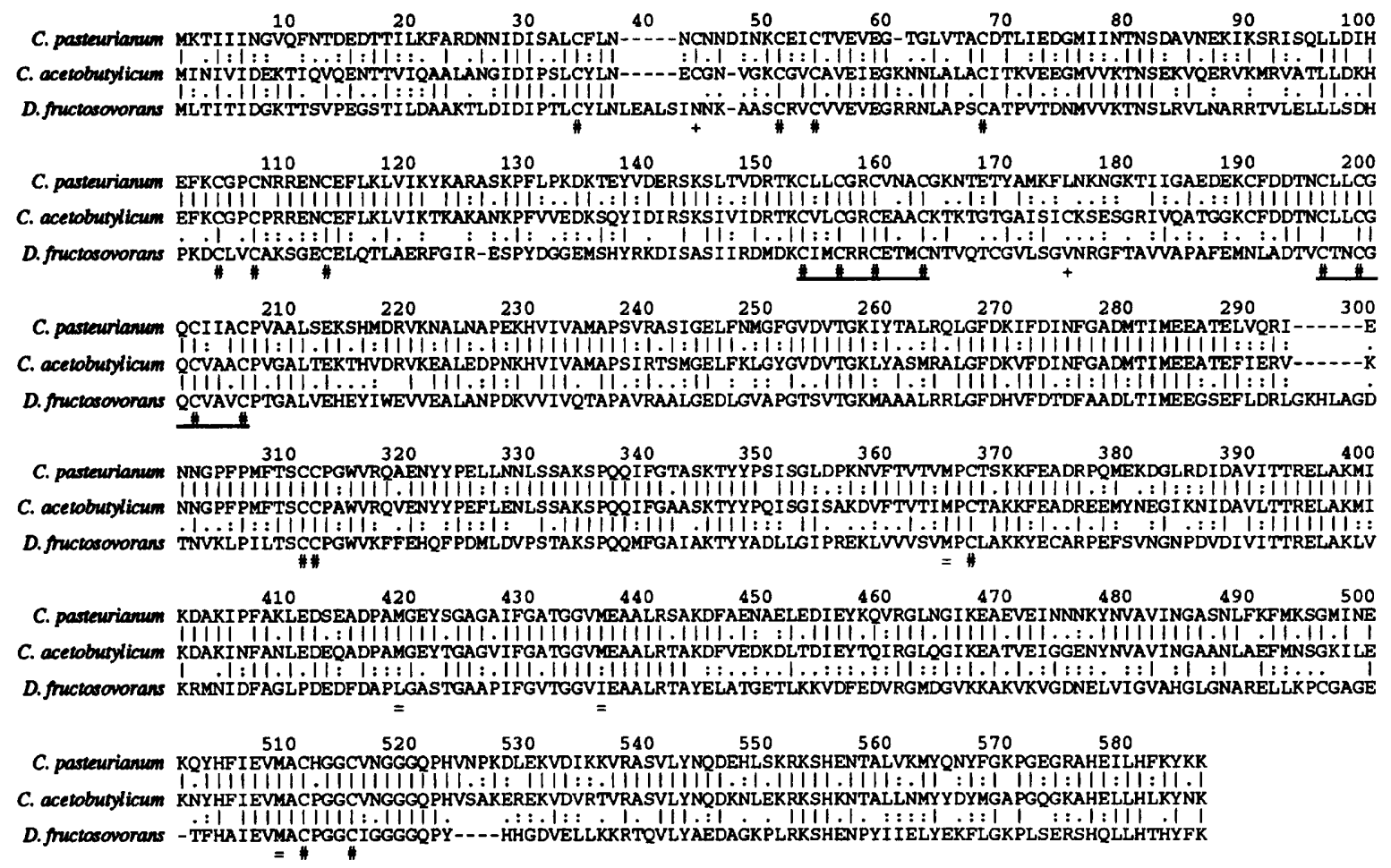

\begin{abstract}
Fig. 6. Comparison of the amino acid sequences of the $C$. acetobutylicum HydA, $C$. pasteurianum hydrogenase-1 and $D$. fructosovorans NAD-reducing hydrogenase (4th subunit) proteins. The symbol comparison table described by Gribskov \& Burgess (1986) was used to calculate percentage similarity and percentage identity. The symbols between the sequences are as follows: |, identity; : and ., closer and further evolutionary distance between similar amino acids, respectively. The symbols below the sequences are as follows: \#, conserved cysteine residues; + , additional cysteine residues in the $C$. acetobutylicum and $C$. pasteurianum sequences; $=$, conserved methionine residues. The two regions containing cysteine residues in a [4Fe-4S] ferredoxin-like pattern are underscored.
\end{abstract}

genase activity was similar in both acid- and solventproducing cells. Hydrogenase activity in solvent-producing cells could only be detected in this assay after an initial lag period of 10-15 min, and these authors concluded that the hydrogenase from the solvent-producing cells was present in an inactive form and the conditions used for the assay activated the enzyme after a lag period.

The decrease in hydrogen production associated with solventogenesis in C. acetobutylicum could simply be due to a decreased availability of reduced ferredoxin. Perhaps then, the NADH-ferredoxin-oxidoreductase is the site of solventogenesis associated induction or derepression in C. acetobutylicum, and when present in its most active form would recycle ferredoxin to its oxidized state in preference to the hydrogenase enzyme, thereby meeting the increased demands of the cell for NADH. The results presented here in Figs. 4 and 5 support this hypothesis, as no difference was noted in byd $A$ transcript levels with RNA isolated from either acid-producing or solvent-producing cells. It should be mentioned that, overall, byd $A$ transcript levels were found to be low and, therefore, minor differences in gene expression at the level of transcription and post-transcriptional regulation cannot be ruled out. Although only representative samples are presented, a large number of RNA samples were prepared from all growth stages of a $C$. acetobutylicum fermentation, and in all cases the transcript size and expression level was equivalent to the results in Fig. 4. It can therefore be concluded that the byd $A$ gene from $C$. acetobutylicum is constitutively expressed from a monocistronic operon throughout the course of a typical batch fermentation.

The $5^{\prime}$ end of the byd $A$ transcript was identified via primer extension, and these results indicated that only one transcription initiation site is utilized in both acidproducing and solvent-producing $C$. acetobutylicum cells (Fig. 5). Based on these primer extension results, a putative promoter sequence from positions 381 to 409 could be deduced (TTATTT-17 bp-TAAAAT; see Fig. 3 ); the proposed Gram-positive promoter consensus sequence is TTGACA-16 to 18 bp-TATAAT (Graves \& Rabinowitz, 1986; Young et al., 1989). Apart from the traditional promoter core regions, it is apparent that in Gram-positive organisms, upstream and downstream regions also display conserved sequences (Graves \& Rabinowitz, 1986). Conservation of nucleotide sequences in the extended regions can compensate for a lack of conservation in the core regions. For example, a TG pair starting 3 bp upstream of the -10 region has been shown to be sufficient to compensate for the absence of a specific -35 region (Ponnambalam et al., 1986; Keilty \& Rosenberg, 1987). The proposed -35 region for the byd $A$ gene is indeed very poorly conserved. However, 
there is a TG pair located $3 \mathrm{bp}$ upstream of the well conserved -10 region (see Fig. 3). The similarity of this putative promoter region to consensus sequences for vegetative sigma factors in $\mathrm{Gram}$-positive bacteria and $E$. coli adds further support to the conclusion that the byd $A$ mRNA is constitutively produced by $C$. acetobutylicum.

\section{ACKNOWLEDGEMENTS}

J. Santangelo acknowledges financial support obtained from the Alexander von Humboldt Stiftung, which allowed him to continue this work in Germany. Thanks are also owed to Jaques Meyer who provided the $C$. pasteurianum hydrogenase- 1 clone which was used to screen the $C$. acetobutylicum gene library.

\section{REFERENCES}

Adams, M. W. W. (1990). The structure and mechanism of ironhydrogenases. Biocbim Biophys Acta 1020, 115-145.

Allcock, E. R., Reid, S. J., Jones, D. T. \& Woods, D. R. (1982). Clostridium acetobutylicum protoplast formation and regeneration. Appl Environ Microbiol 43, 719-721.

Altschul, S. F., Gish, W., Miller, W., Myers, E. M. \& Lipman, D. J. (1990). Basic local alignment search tool. J Mol Biol 215, 403-410.

Andersch, W., Bahl, H. \& Gottschalk, G. (1983). Level of enzymes involved in acetate, butyrate, acetone and butanol formation by Clostridium acetobutylicum. Eur J Appl Microbiol Biotechnol 18, 327-332.

Beinert, H. (1990). Recent developments in the field of iron-sulfur proteins. F ASEB J 4, 2483-2491.

Bertram, J. \& Durre, P. (1989). Conjugal transfer and expression of streptococcal transposons in Clostridium acetobutylicum. Arch Microbiol 151, 551-557.

Brendel, V. \& Trifonov, E. N. (1984). A computer algorithm for testing potential prokaryotic terminators. Nucleic Acids Res 12, 4411-4427.

Burchhardt, G. \& Durre, P. (1990). Isolation and characterization of DNase-deficient mutants of Clostridium acetobutylicum. Curr Microbiol 21, 307-311.

Cunningham, R. P., Asahara, H., Bank, J. F., Scholes, C. P., Salerno, J. C., Surerus, K., Munck, E., McCracken, J., Peisach, J. \& Emptage, M. H. (1989). Endonuclease III is an iron-sulfur protein. Biochemistry 28, 4450-4455.

Datta, R. \& Zeikus, J. G. (1985). Modulation of acetone-butanolethanol fermentation by carbon monoxide and organic acids. Appl Environ Microbiol 49, 522-529.

Devereux, J., Haeberli, P. \& Smithies, O. (1984). A comprehensive set of sequence analysis programs for the VAX. Nucleic Acids Res $12,387-395$.

Gapes, J. R., Larsen, V.F. \& Maddox, I. S. (1982). Microbial production of $n$-butanol: some problems associated with the fermentation. In Energy from Biomass, Proceedings of the 14th Biotechnology Conference, pp. 90-101, Palmerston North, New Zealand.

Gerischer, U. \& Durre, P. (1992). mRNA analysis of the adc gene region of Clostridium acetobutylicum during the shift to solventogenesis. J Bacteriol 174, 426-433.

Graves, M. C. \& Rabinowitz, J. C. (1986). In vivo and in vitro transcription of the Clostridium pasteurianum ferredoxin gene. J Biol Chem 261, 11409-11415.

Gribskov, M. \& Burgess, R. R. (1986). Sigma factors from E. coli, B. subtilis, phage SP01 and phage T4 are homologous proteins. Nucleic Acids Res 14, 6745-6763.

Hausinger, R. P. \& Howard, J. B. (1983). Thiol reactivity of the nitrogenase $\mathrm{Fe}$-protein from Azotobacter vinelandii. J Biol Chem 258, 13486-13492.

Henikoff, S. (1984). Unidirectional digestion with exonuclease III creates targeted breakpoints for DNA sequencing. Gene 228, 351-359.

Ish-Horowicz, D. \& Burke, J. F. (1981). Rapid and efficient cosmid cloning. Nucleic Acids Res 9, 2989-2998.

Jones, D. T. \& Woods, D. R. (1986). Acetone-butanol fermentation revisited. Microbiol Rev 50, 484-524.

Jones, D. T., van der Westhuizen, A., Long, S., Allcock, E. R., Reid, S. J. \& Woods, D. R. (1982). Solvent production and morphological changes in Clostridium acetobutylicum. Appl Environ Microbiol 43, 1434-1439.

Keilty, S. \& Rosenberg, M. (1987). Constitutive function of a positively regulated promoter reveals new sequences essential for activity. J Biol Chem 262, 6389-6395.

Kim, B. H. \& Zeikus, J. G. (1985). Importance of hydrogen metabolism in regulation of solventogenesis by Clostridium acetobutylicum. Dev Ind Microbiol 26, 1-14.

Kim, B. H., Bellows, P., Datta, R. \& Zeikus, J. G. (1984). Control of carbon and electron flow in Clostridium acetobutylicum fermentations: utilization of carbon monoxide to inhibit hydrogen production and to enhance butanol yields. Appl Environ Microbiol 48, 764-770.

Lin, Y.-L. \& Blaschek, H. P. (1984). Transformation of heat-treated Clostridium acetobutylicum protoplasts with pUB110 plasmid DNA. Appl Environ Microbiol 48, 737-742.

Manoil, C. \& Beckwith, J. (1985). Tnpho $A$ : a transposon probe for protein export signals. Proc Natl Acad Sci US A 82, 8129-8133.

Marmur, J. (1961). A procedure for the isolation of deoxyribonucleic acid from microorganisms. J Mol Biol 3, 208-218.

Martin, J. R., Petitdemange, H., Marczak, R. \& Gay, R. (1982). A study of $\mathrm{NAD}(\mathrm{P})$ oxidoreductases of Clostridium acetobutylicum involved in the metabolism of glucose. In Industrielle et Biotechnologie. Production d'Intermediares Industriels par Culture Anaerobie, pp. 123-138. Edited by O. Chaude \& G. Durand. Paris: Société Française de Microbiologie.

Meyer, J. \& Gagnon, J. (1991). Primary structure of hydrogenase I from Clostridium pasteurianum. Biochemistry 30, 9697-9704.

Meyer, C. L., McLaughlin, J. K. \& Papoutsakis, E. T. (1985). The effect of $\mathrm{CO}$ on growth and product formation in batch cultures of Clostridium acetobutylicum. Biotechnol Lett 7, 37-42.

Meyer, C. L., Roos, J. W. \& Papoutsakis, E. T. (1986). Carbon monoxide gassing leads to alcohol production and butyrate uptake without acetone formation in continuous cultures of Clostridium acetobutylicum. Appl Microbiol Biotechnol 24, 159-167.

Mortenson, L. E. \& Chen, J. S. (1975). Hydrogenases. In Microbial Production and Utilization of Gases, pp. 69-74. Edited by H. G. Schlegel, G. Gottschalk \& N. Pfennig. Göttingen, Germany: Goltze.

Needleman, S. B. \& Wunsch, C. D. (1970). A general method applicable to search for similarities in the amino acid sequence of two proteins. J Mol Biol 48, 443-453.

O'Brien, R. W. \& Morris, J. G. (1971). Oxygen and the growth and metabolism of Clostridium acetobutylicum. J Gen Microbiol 68, 307-318.

Oelmuller, U., Kruger, N., Steinbuchel, A. \& Friedrich, C. G. (1990). Isolation of prokaryotic RNA and detection of specific $m R N A$ with biotinylated probes. J Microbiol Methods 11, 73-84.

Ponnambalam, S., Webster, C., Bringham, A. \& Busby, S. (1986). 
Transcription initiation in the Escherichia coli galactose operon promoters in the absence of the normal -35 region sequences. $J$ Biol Chem 261, 16043-16048.

Sambrook, J., Fritsch, E. F. \& Maniatis, T. (1989). Molecular Cloning: a Laboratory Manual, 2nd edn. Cold Spring Harbor, NY: Cold Spring Harbor Laboratory.

Sanger, F., Nicklen, S. \& Coulson, A. R. (1977). DNA sequencing with chain-terminating inhibitors. Proc Natl Acad Sci USA 74, 5463-5467.

Sauer, U. \& Durre, P. (1993). Sequence and molecular characterization of a DNA region encoding a small heat shock protein of Clostridium acetobutylicum. J Bacteriol 175, 3394-3400.

Southern, E. M. (1975). Detection of specific sequences among DNA fragments separated by gel electrophoresis. $J$ Mol Biol 98, 503-517.

Spivey, M. J. (1978). The acetone/butanol/ethanol fermentation. Process Biochem 13, 2-5.

Stokkermans, J., van Dongen, W., Kaan, A., van den Berg, W. \& Veeger, C. (1989). bydy, a gene from Desulfovibrio vulgaris (Hildenborough) encodes a polypeptide homologous to the periplasmic hydrogenase. FEMS Microbiol Lett 58, 217-222.

Tabor, S. \& Richardson, C. C. (1987). DNA sequence analysis with a modified bacteriophage T7 DNA polymerase. Proc Natl Acad Sci US $A$ 84, 4767-4771.

Thauer, R. K., Kăufer, B., Zăhringer, M. \& Jungermann, K. (1974). The reaction of the iron-sulfur protein hydrogenase with carbon monoxide. Eur J Biocbem 42, 447-452.

Vasconcelos, I., Girbal, L. \& Soucaille, P. (1994). Regulation of a carbon and electron flow in Clostridium acetobutylicum grown in chemostat culture at neutral $\mathrm{pH}$ on mixtures of glucose and glycerol. $J$ Bacteriol 176, 1443-1450.

Voordouw, G. \& Brenner, S. (1985). Nucleotide sequence of the gene encoding the hydrogenase from Desulfovibrio vulgaris (Hildenborough). Eur J Biochem 148, 515-520.

Voordouw, G., Strang, J. D. \& Wilson, F. R. (1989). Organization of all genes encoding [Fe] hydrogenase in Desulfovibrio vulgaris subsp. oxamicus Monticello. J Bacteriol 171, 3881-3889.

Wilkinson, S. R. \& Young, M. (1993). Wide diversity of genome size among different strains of Clostridium acetobutylicum.J Gen Microbiol 139, 1069-1076.

Woods, D. R. \& Jones, D. T. (1986). Physiological responses of Bacteroides and Clostridium strains to environmental stress factors. Adv Microb Pbysiol 27, 1-64.

Yanisch-Perron, D., Vieira, J. \& Messing, J. (1985). Improved M13 phage cloning vectors and host strains: nucleotide sequences of M13mp8 and pUC19 vectors. Gene 33, 103-119.

Yerushalmi, L. \& Volesky, B. (1985). Importance of agitation in acetone-butanol fermentation. Biotechnol Bioeng 27, 1297-1305.

Young, M., Minton, N. P. \& Staudenbauer, W. L. (1989). Recent advances in the genetics of the clostridia. FEMS Microbiol Rev 63, 301-325.

Zappe, H., Jones, D. T. \& Woods, D. R. (1986). Cloning and expression of Clostridium acetobutylicum endoglucanase, cellobiase and amino acid biosynthesis genes in Escherichia coli. J Gen Microbiol 132, 1367-1372.

Received 20 June 1994; revised 30 August 1994; accepted 28 September 1994. 